\title{
Shift of Creativity Concepts: From Mysticism to Modern Approach
}

\author{
GINTARÉ ADOMAITYTE்', VIKTORIJA ŽILINSKAITE்², ŽIVILE் SEDEREVIČIŪTÉ- \\ PAČIAUSKIENE் ${ }^{2}$, ILONA VALANTINAITE் ${ }^{3}$, VIDA NAVICKIENÉ ${ }^{3}$ \\ $1 \%$ Arabica Berlin Kreuzberg, Reichenberger Str. 36, 10999 Berlin \\ Email: adomaityte.gintare@yahoo.com \\ ${ }^{2}$ Department of Creative Communication, Faculty of Creative Industries, Vilnius Gediminas Technical University, 1 Trakų Street, 01132 Vilnius \\ Email: viktorija.zilinskaite@vgtu.It; zivile.sedereviciute-paciauskiene@vgtu.lt \\ ${ }^{3}$ Department of Philosophy and Cultural Studies, Faculty of Creative Industries, Vilnius Gediminas Technical University, 1 Trakų Street, \\ 01132 Vilnius \\ Email: ilona.valantinaite@vgtu.lt; vida.navickiene@vgtu.lt
}

\begin{abstract}
The article analyses the development of creativity concepts. Notions of creativity transformed historically from uncontrolled divine inspiration and non-reflected artistic inspiration to the targeted work resulting in commercially successful creative products. The analysis begins with Plato's discussion that a poet should be overtaken by divine inspiration, that human beings do not create by themselves, they are dictated to by the Muses. Renaissance, Rationalism and Romanticism are analysed including their reflections in recognised artists of 20th century. Today's notions of creativity are reviewed including ones important for creative industries and consumer society.
\end{abstract}

Keywords: creativity, concepts, evolution of terms

\section{INTRODUCTION}

Creativity is perhaps the most commonly used concept to talk about the present and future human competences. In recent years creativity has gained huge importance and is fundamental not only to the arts and related activities, which traditionally and historically had always been considered creative, but also is emphasized in business, leadership, information technology, construction, education, management initiatives and personnel management, marketing, public relations, preparation of projects and their effective functioning. Society has always been striving for creativity and this aspiration has always been predetermined by both historical circumstances and political order (Pope 2005: 20). Subject to the period, the term has acquired different meanings depending on both social and economic conditions, the public approach and lifestyle, as well as the role of education in human mentality and identity. Areas, which had traditionally been perceived creative, began to transform, changing the concept of creativity and expanding the spectrum of its use. With the development of the perception of creativity, both the definition of the concept and the society's approach to it have been changing: from the elitist, exceptional, 
heavenly artistry, measured in terms of designed products and their quantity, to a much broader description, which states that the day-to-day activities, the ability to see a rational, original, outstanding decision is also a feature of creativity. Creativity has acquired different meanings: it has been a search for something new, generation of new ideas, and breakthrough. Historical development of the concept shows that it is 'an ever-developing and self-renewing concept' (Seyfi et al. 2017: 123). Recently, all of this has been combined into one definition - influences, derived from the environment that enable people to work and produce/develop creative products (Hemlin 2004: 1).

The article aims to analyse the relation between the notion of creativity and its social and cultural conditions. For the analysis of creativity concepts a mapping review (Grant et al. 2009: 97) is used as methodology of the research.

\section{MAIN DIRECTIONS IN SHIFTS OF CREATIVITY CONCEPTS: FROM THE HEROIC CREATOR TOTHE LEADER}

As maintained in Strenberg (1999: 3), creativity is the ability to create something new, original, unpredictable, good, adaptive, and performs the intended function. Although the term creativity seems to be usual and familiar, the term (and even the word) was not in use before the end of 20 th century. The English term 'creativity' was first mentioned in 1875 . Of course, the cognate terms - 'creation', 'creator', 'to create' - had been introduced earlier with reference to religion and, later, to artistry (Pope 2005: 19). Creativity is traditionally associated with arts; however, contemporary understanding of creativity sees it as 'equally important in technical innovation, training, education and business, arts and science' (Runco 2014: 9). Looking at creativity from the history of art, creator's image in relationship with the public and the development of art perspectives, one may notice the contrasting terms of a creator and creativity that reflect the development and perception of the concept of creativity at a given period of time. Five main aspects are seen in the change: the origin of creativity, the image of a creator, processes, and borders of creativity.

\section{ORIGINS OF CREATIVITY - FROM EXTERNAL DIVINE TO INTERNAL PSYCHOLOGICAL}

Before the modern scientific era creativity was related to superhuman powers. 'Many ancient Greeks believed that inspiration and creation resulted from divine intervention' (Batey 2012: 56). An individual was not understood as able to create something that did not exist before on his own. According to the then common belief, a man could not devise anything new and had only been a tool for the manifestation of the divine, which had been considered the real creator in a human form, while the creative process had been associated with inspiration (which had also been considered divine). Inspiration and respiration related creativity to divine power as the first impulse of any creative action. Plato (427-327 BC) discussed the fact that the poet must be embraced by the divine and be guided by the Muses (Platonas 1996: 40). Plotinus (204-270 BC) saw value only in the art originating from God (Plotinus 1917: 37). Beauty as the symbol of morality was seen by Immanuel Kant (Kant 1987: 225). Rudyard Kipling once claimed that one has to wait for a 'demon' that resides in the writer's pen - 'When your Daemon is in charge, do no try to think consciously. Drift, wait and obey' (Kipling 1990: 122-23). Thus, the man himself had not been perceived as a creator and had only been assisting the mystical powers and God's capabilities in a physical form; however, his brain, ideas or the abilities have never been evaluated before. Move towards understanding about the value as an agreeable, not absolute, value is already seen in ideas of David Hume: 'Handsome and beautiful, on most occasions, is not an absolute but a relative quality, and pleases us by nothing but its tendency to produce an end that is agreeable' (Hume 1965: 557). However, the contemporary understanding of creativity sees origins in the psychological construction of personality and the interaction between consciousness and 
unconsciousness (Cascio, Martin 2011: 51), not a divine or mystic origin, but a human psychological structure as such. Focusing on the contemporary discourse we may even find 'that realism is the best philosophical doctrine for helping scientists to increase their theoretical and empirical creativities' (Park 2016: 124). The shift from divine/metaphysic turned to internal attitudes of the creating human that can be taught 'learners $\langle\ldots\rangle$ showed $\langle\ldots\rangle$ higher creativity' (Yasmin et al. 2017: 145), not only acquainted through inspiration.

\section{CREATOR'S IMAGE AND ITS CHANGE}

The second evident change is between the images of a creator. The first dichotomy is between high and low social statuses. One of dichotomy oppositions sees artists as working alone, being awarded with special heavenly powers or allegedly being geniuses and, therefore, having a high social status and recognition. Creators had to sign their works to help consumers identify them, as even an indirect contact with or the knowledge about the creator was very important - 'Creative genius is a talent, a gift' (Mccreery et al. 2016: 110). Another position in dichotomy is the following: an alienated artist that avoids socialization - 'creativity resides with the work of a solitary genius' (Street et al. 2018: 68). This was based on understanding that 'creativity does not react to orders' (Kronfeldner 2009: 588). Art creators had to live in remote areas, be mysterious and segregated, sometimes even mentally ill (Cohen 2012: 7). This second image linked artists to a low status and poverty. Contemporary representations in popular culture may include both avoidance of socialization and high social positions, e.g. doctor House from the House series (Jacoby 2009: 235). The example manages to integrate both oppositons.

The second dichotomy is between message and technique. Artists non-depending on high-low societal status were understood as having a mission to communicate a unique message. The part of the image overtook association with technique (seen in even semantic relation between an artist and an artisan). Before the Renaissance, creativity had been associated with the ability to replicate the well-known cities, great masters, as well as reality (Becker 2000-2001: 46). Exceptions were artists, such as Leonardo da Vinci or Giorgio Vasari, making attempts to prove that the genius did not have to only imitate, but rather had to be original and demonstrate an individual perspective. The 19th century Europeans began to perceive artists as they are described today, i.e. individuals, who integrate both the academic quality and originality, creators, who express and communicate an original vision via meaningful works.

The image of a creator changed a lot when a creative personality became the focus of scientific analysis: 'Qualities of a creative personality are analysed by the representatives of the humanistic philosophical school of thought' (Šliogerienè et al. 2017: 86). Social position, however, is understood through the concept of collateral social hierarchy (having a high symbolic value and prestige like the same socioeconomic position of the main social hierarchy) that is never perceived through the same positions as the dominant one. Contemporary understanding points out knowledge and targets as driving forces for a creator. 'Thus creativity never starts from nothing' (Hołub et al. 2016: 114). While relating creativity with processes that look for solutions or inventions we have to notice that creativity is no longer seen as 'exclusively human activity' (Kudryashev et al. 2017: 137). In addition to a solitary creator different forms of collective creativity emerged, e.g. creative clusters (Danko et al. 2017: 31), collective creativity, etc.

\section{THE INFLUENCE OF ROMANTICISM AND RATIONALISM MOVEMENTS ON THE CREATOR'S RECEPTION}

The third historical development is multiple changes from rational to romantic perceptions and vice versa. The influence of rationalism and romanticism on creativity had some impact on 
the assessment of the creative process, creators and their works. The Rationalism movement saw creativity as stemming from awareness, intelligence and rational thinking, while the Romanticism derived creativity from the irrational thinking, maintaining the idea that rational consciousness impedes the creative process.

Perception of creativity was primarily associated with rationality. 2300 years ago, Aristotle pointed out awareness and rationality, and highlighted that rational work necessitated creative inspiration for what would be a created product. The Rationalist perception was being adhered to during the European Renaissance when causality was considered to be the most valuable dimension. Causality, knowledge, teaching and education were considered vitally important for the creation of valuable art, and the term 'originality' brought the meaning of novelty, but this was not considered a radical subversion of customs and traditions. In the 18th century, the new term 'genius' was mainly used to define creative individuals and was primarily associated with both rationalism and conscious processes. Scientists and artists, whose achievements were based on imagination, thought and criticism, were considered geniuses.

The Romanticists, on the contrary, believed that rational consciousness withdraws creative impulses. Instead of rational, consciousness-based thinking, an artist should rather listen to the inner muses and create unconsciously. The supporters of the movement claimed that creativity requires at least momentarily extricating oneself from consciousness, relying on emotions and instincts, and, therefore, imagination had a greater value than traditional capabilities. 'Stereotype of the creative Romantic artist of the eighteenth century or the individually heroic, defiant abstract expressionist of the twentieth: the lone (male) genius, solitary in his pursuit' (Brand 2015: 34). The period of Romanticism encouraged the perception of the creator as an individual of a higher social status due to internal spiritual distinctness.

At the end of the 19th century, the Pendulum change between both attitudes started. Antiromanticism began to gain popularity - the rebirth of Rationalism in the 20th century was called Modernism. It was defined by isolation, coldness and segregation. Later, the expressionists stated that the necessary condition for creation is spontaneity, relying on emotions, inspiration, without rational ideas or willful filtering of ideas. The Avant-garde art period faced the return to neo-romantic ideas. Contemporary art (sometimes called Postmodernism) was associated with the return to rationalism. Proponents of Postmodernism were critical of the concept of creativity - they deconstructed thoughts about spontaneity, individuality and individual genius. The convictions of Romanticism about art were rejected during the period of Minimalism and Pop Art, when Andy Warhol stated: 'I want to be a machine'. During this period, the ideas of authenticity and personal commitment were rejected; thus, the society often avoids modern art and the perception of creativity, as an average person is still guided by the Romanticism's understanding of creativity.

\section{CREATIVITY AND LEADERSHIP}

One may perceive creativity as the expression of an absolutely new behaviour, unique ideas, perfect and/or heroic emotions, as well as the consequence or a vital function of everyday life, the artist's status or professional characteristics. Any artist's goal is creation, dispersion of original ideas and insights. Thus, artists are considered to be capable of depicting the familiar to the public world in a completely new way. This concept of creativity is known as 'heroic creativity'.

The 20th century, also known as 'The Age of Creativity', faced the expansion of the creativity borders, questioning the status of artists, who claim to be the only ones able to produce creative products. Creativity 'is a key element of the skills needed for success in the 21st century' (Hondzel et al. 2015: 185). 
Business leaders, who develop and apply innovative company management methods, IT professionals and scientists/scholars, whose work results are gauged by creativity criteria, are more often referred to as creative personalities. The term 'creativity' connotes various meanings - derived from the high art, today this term has a changing connotation in the society (Hesmondhalgh 2013: 170). Creativity may be defined as something assisting in the development of anything new as well as problem solving. 'All kinds of creativity are aimed at the transformation of the world and the subject of creativity itself' (Stoletov 2016: 141). Psychologists claim that problem solving is the most important aspect of creativity, while uniqueness is its constituent part. Thus, creativity is being applied in business problem solving and is perceived through features mainly related to target and achievement 'using imagination, pursuing purposes, being original and being of value' (Esjeholm 2015: 231). Applying the before mentioned qualities, leaders are able to cope with challenges in the modern society, are confident to motivate their team members, and promote 'out-of-the-box' thinking.

The shifts in the modern economy have promoted creativity, which is economically vital. The concept of romanticism art in the society has strengthened the western perception that creation is a reflection of the creator, contrasting creativity and commerce (Hesmondalgh 2013: 28). Generally, artists are allegedly considered to be most creative, since their works reflect the individual new approach. Nevertheless, currently, with the establishment of the creative industries concept, the range of the creativity concept has been expanded, rejecting the common belief in heavenly inspiration or the existence of the genius. Creativity has become crucially important in creative industries and leadership, as it makes an impact on the technological innovations, and helps create an extra value in the knowledge and creative economies. Phrase 'creativity and innovation' became a collocation (e.g. Burns et al. 2015; Lim 2016). The modern creativity concept of the 21th century is more often related to innovations in business as well as in the development and implementation of technologies. In addition to that we see the back effect of the attitude towards understanding of creativity in arts - 'musicians' creativity $<\ldots>$ focused not on the explanation of the world (or at least capturing it in the images), but on changing it' (Sautkin 2017: 60). Responding to social conditions with creativity became an essential feature for both artistic (classical understanding about creativity) (Dorchin 2017: 171) and non-artistic creativity (contemporary understanding about creativity). Relationship between creativity and change is seen in scientific field as well, it is understood that 'scientific creativity makes scientific progress possible' (Park 2017: 97). The shift represents deterritorialization of the concept from the field of arts to broad and general leadership fields of social development.

Summarising change from a heroic creator to the leader we may see a reverse correlation and change. Looking from the perspective of art criticism, one may observe the differences in the approach to creativity, i.e. from that of heavenly inspiration to the leader - the rational inspiration for the surrounding. Interrelating creativity with the holistic approach, one may notice the devaluation of personal skills with a special emphasis on the divine, mystic power, creating through the individual by means of their tangible, physical substance. Thus, the critical dimension is not perceived to the fullest, as the fruits of God cannot be imperfect, and hence, criticized. In the context of the shift from the Romanticism ideologies to those of the Rationalism, the status of the creator as well as their products were transformed: the creator has acquired a completely different status, moved to a higher level in the society, and has been mentally supported by the rich, while their works have been perceived as the craftsman's products, and later their artistic and aesthetic aspects have been analysed. Creativity, directly related with artistry, has been shifting from heroism to leadership. Nowadays, creativity is identified with artistry, but 
may equally be highlighted as an indispensable necessity when working in the company, which develops products that are not related to arts or entertainment industry. In the 21th century, most of the industries will depend on the ability to utilize knowledge and creativity, as well as the skills needed to develop innovations, merging them with precise systems (Landry, Bianchini 1995: 12). This means that the abilities to inspire and reorganize the habitual things are increasingly important for the development of anything new and anticipation of new combinations that would be beneficial to the society.

\section{DISCUSSION: THE CREATIVITY ASSUMPTIONS CONCEPT - FROM A STARVING ARTIST TO INDIVIDUAL SELF-REALIZATION}

The importance of creativity was realized, however, it still needs deeper research and analysis, as only the key factors of intelligence - memory, logical justification, concentration and retention of attention - have been in the focus of analysis. After the creativity discourse has gained popularity in the society, psychologists, sociologists, anthropologists, art critics, and artists began to delve into creativity as a research object.

Lately, creativity studies have become interdisciplinary and gained both social and cultural aspects, interpreting both creative people and their activities, social and cultural development context. The blended approach has brought together researchers of different areas, in particular those who were interested in art, verbal rituals of creativity in various activities. The research of social sciences specialists has highlighted that both individual perception and inspiration, as well as social factors such as sociality, supporting networks, education, certain training and cultural background are necessary for the definition of creativity. Creativity may be explained by merging the psychological research of individuals, the sociological analysis of how individuals create in groups, and the anthropological research on perception and evaluation of creative products of people with different cultural and social beliefs (Sawyer 2006: 4). At the beginning of the analysis of creativity it has been observed that culture, environment and society, which evaluates the creative processes and products, are equally important. The ability to create comes from the individual's inner world, feelings, experiences, ideas, and is influenced by the external factors, especially by the society in which one creates. Both context, social and historical aspects are crucially important for the efficient creative process, analysed by social sciences.

The greatest part of creativity research, carried out by art critics and historians, has been limited by the forms of art, mostly valued and appreciated in the Western Europe. The analysis has been focused on the high art forms; much attention has been paid to visual art rather than to painting, graphics or animation, to symphonic compositions rather than to jazz groups' creative improvisation. The analysis of different creative behaviour models, high Western European art, as well as comics, movies, music videos, jazz improvisations, rock performances and manifestations of various genres has gained importance for the attempts to define creativity. The analysis of the mentioned forms of creativity, which is related to art criticism and history, provides the opportunity to make an insight into various creative methods: the implementation of technologies, teamwork and inception of spontaneity dimension. Various scientific approaches have been applying different methods, focused on the creative individual and the process, in the course of which the creative product is being developed, or the result. The mere fact that scientific research has been emphasizing different aspects of creativity demonstrates the polysemy of the term 'creativity'.

Despite the attempts of the scientific discourse to analyse creativity, there is still no clearcut status of creativity. Although there have been different approaches, they all share a common trait - a positive approach to creativity, usually in conjunction with the highest possible human achievement. The attempts to 
scientifically define creativity have been made by psychologists and social sciences researchers, whose goal was to identify the specific cognitive, operating and motivating factors that contribute to and promote the creation.

Scientists analysing creativity have been focusing their attention on the personality psychology, individual character features and behaviour patterns, which reveal that the achievement of the creative expression requires self-contribution, but not the muse or inspiration: active monitoring, interest in environmental phenomena and processes, analysis, professional knowledge, intellectuality and the ability to apply the available information, the impact of recognition and striving for original solutions, unusual relationships. However, the individual ambition, environment and culture, which influence, promote or paralyse the creator, are very important, as the use of the term 'creative', according to psychologists, 'relates to the description of products, reflecting the social community' (Sawyer 2006: 35). Also, the ability or quality of belongingness to a community is vital for creativity. There exist such forms of creativity that are only possible due to the collaboration of individuals. Although the scientific approach to creativity does not yet have a strong research basis, it is obvious that the ability to develop individually and communicate with the environment makes an impact on the creative production process and its outcome.

\section{CONCLUSIONS}

To sum up, the transformation of the concept of creativity gives meaning to the multidimensionality: both traditional and present perception of the term helps understand the nature of creativity, the creative individual and the developed product, its essential characteristics and assessment by society during a specific historical period. The importance of creativity is more often highlighted in various fields, paying attention both to the individual, creative process and its result - the utility, novelty and applicability of the product. The applicability of the product is considered one of the most important characteristics, necessary to carry out any activity or to be a mature person, striving for self-expression. Looking at the development of creativity concepts in the context of both the scientific and practical activities, from the creators and society's perspective, as well as the audience and product's relationship, one may observe the importance of the transformation of the concept: from high art, unique, divine creation that exists due to the mystical inspiration, the perception of art as a craft, special mission - the communication of a message to the society, tolerance of madness that is considered a certain form of the genius, alienation and individualism to creation in a team, combination of new, innovative, original ideas, introduction of the dimension of applicability, and the statement 'to create means to exist'.

Received 16 May 2018

Accepted 4 July 2018

\section{References}

1. Batey, M. 2012. “The Measurement of Creativity: From Definitional Consensus to the Introduction of a New Heuristic Framework", Creativity Research Journal 24(1): 55-65.

2. Becker, G. 2000-2001. "The Association of Creativity and Psychology: Its Cultural-Historical Origins", Creativity Research Journal 13(1): 45-53.

3. Brand, P. Z. 2015. "The Role of Luck in Originality and Creativity", The Journal of Aesthetics and Art Criticism 73(1): 31-55.

4. Burns, T. R.; Machado, N.; Corte, U. 2015. "The Sociology of Creativity: Part I: Theory: The Social Mechanisms of Innovation and Creative Developments in Selectivity Environments", Human Systems Management 34: 179-199.

5. Cohen, L. M. 2012. "Adaptation and Creativity in Cultural Context", Revista de Psicología 30(1): 3-18.

6. Danko, L.; Bednář, P.; Matošková, J. 2017. "Managers' Activities Within Cultural and Creative Clusters: An Essential Element for Cluster Development in the Visegrád Countries", Creativity Studies 10(1): 26-42.

7. Dorchin, U. 2017. "In Search of Creative Expression: The Dialectics of Race, Politics, and Literature in Caribbean Dub Poetry”, Creativity Studies 10(2): 159-173. 
8. Esjeholm, B. 2015. "Design Knowledge Interplayed with Student Creativity in D \& T projects", International Journal of Technology and Design Education (123): 227-243.

9. Grant, M. J.; Booth, A.; Centre, S. 2009. "A Typology of Reviews: An Analysis of 14 Review Types and Associated Methodologies", Health Information and Libraries Journal (26): 91-108.

10. Hołub, G.; Duchliński, P. 2016. "Creativity in Philosophy and in Science How Philosophy Can Help in Creative Thinking", Creativity Studies 9(2): 104-115.

11. Hondzel, C. D.; Hansen, R.; Hondzel, C. D.; Hansen, R. 2015. "Associating Creativity, Context, and Experiential Learning", Education Inquiry 6(2): 177-190.

12. Hume, D. 1965. A Treatise Human Nature. Oxford: The Clarendon Press.

13. Jacoby, H. 2009. House and Philosophy. Hoboken, N. J.: John Wiley \& Sons, Inc.

14. Kant, I. 1987. Critique of Judgment. Indianapolis/Cambridge: Hackett Publishing Company.

15. Kronfeldner, M. E. 2009. "Creativity Naturalized", The Philosophical Quarterly 59(237): 577-592.

16. Kudryashev, O. I.; Elkhova, A. F. 2017. "The Creative Ability of Artificial Intelligence”, Creativity Studies 10(2): 135-144.

17. Lim, W. M. 2016. "A Blueprint for Sustainability Marketing", Marketing Theory 16(2): 232-249.

18. Mccreery, J.; Word, T. 2016. "Conditions of Creativity: Adding Historical Perspective", Journal of Business Anthropology 5(1): 105-115.

19. Park, S. 2016. "How to Foster Scientists' Creativity", Creativity Studies 9(2): 116-125.

20. Park, S. 2017. "Selective Realism Versus Individual Realism for Scientific Creativity", Creativity Studies 10(1): 97-107.

21. Platonas. 1996. Faidras. Vilnius: Aidai.

22. Plotinus. 1917. The Beautiful. London: John M. Watkins.

23. Sautkin, A. 2017. "Subculture's Creativity as an Identity Formation Mechanism", Creativity Studies 10(1): 59-71.

24. Seyfi, M.; Güven, D. 2017. "Analysis of Individual and Social Effects of Creative Events", Creativity Studies 10(2): 122-134.

26. Stoletov, A. 2016. "Social Creativity and Phenomenon of Success in Postindustrial Society", Creativity Studies 9(2): 141-150.

27. Street, J.; Negus, K.; Behr, A. 2018. "Copy Rights: The Politics of Copying and Creativity", Political Studies 66(1): 63-80.

28. Strenberg, J. R.; Liubart, I. T. 1999. Handbook of Creativity. Cambridge: Cambridge University Press.

29. Šliogerienè, J.; Valūnaitè-Oleškevičienè, G. 2017. "Evoking Teacher Creativity While Using Social Media", Creativity Studies 10(1): 84-96.

30. Yasmin, M.; Sohail, A.; Sarkar, M.; Hafeez, R. 2017. "Creative Methods in Transforming Education Using Human Resources”, Creativity Studies 10(2): 145-158.

GINTARÉ ADOMAITYTE், VIKTORIJA ŽILINSKAITE், ŽIVILĖ SEDEREVIČIŪTĖ-PAČIAUSKIENĖ, ILONA VALANTINAITE், VIDA NAVICKIENE்

\title{
Kūrybiškumo sampratų raida: nuo mistinio iki vartotojiško
}

\begin{abstract}
Santrauka
Straipsnyje analizuojama kūrybiškumo sampratų raida. Kūrybiškumo sampratos istoriškai transformavosi nuo dieviško ịkvejpimo sukeltų nekontroliuojamų ir nereflektuojamų meninès kūrybos paskatų iki kryptingo darbo sukeliamos komerciškai vertinamų produktų kūrybos. Tyrimas pradedamas Platono diskusija apie tai, jog poetas turi būti apimtas dieviško ịkvejpimo, kad žmogus pats nekuria, jam diktuoja mūza. Renesansui, racionalizmui, romantizmui būdingos kūrybiškumo sampratos analizuojamos aptariant jų atspindžius XX a. pripažintų menininkų pasisakymuose. Šiandieninès kūrybiškumo sampratos, apimančios kūrybinèms industrijoms svarbias koncepcijas, apžvelgiamos iš vartotojiškos visuomenés pozicijų.
\end{abstract}

Raktažodžiai: kūrybiškumas, samprata, terminų raida 